\title{
The Potential of Sea Grapes (Caulerpa Lentilifera) Extracted Polysaccharide as Prebiotics on Inhibiting Pathogenic Bacteria Vibrio Parahaemolyticus
}

\author{
Anek Sopon, Ekthida Thongdet, Porntep Punnarak, and Sucharat Suksai
}

\begin{abstract}
Sea grapes or green cavier (Caulerpa lentilifera), a common tropical green seaweed, consisted of polysaccharides to be used as a prebiotic precursor for prevention of pathogens in aquatic animals. The efficiency of polysaccharides extracted from sea grapes for prebiotic properties was conducted by comparing the growth of probiotic bacteria Bacillus subtilis at different concentrations in co-cultured with pathogenic bacteria Vibrio parahaemolyticus, a gram-negative motile bacterium that inhabits marine and estuarine environments throughout the world, causes of violent diseases outbreak in aquatic animals. The experimental research was 4 treatments with 4 replications including control group (LB broth), extracted sea grape enrichment in LB broth at $0.5,1.0$ and 2.7 mg.C/l. The result showed that the highest growth of probiotic bacteria appeared significantly at extracted sea grape in $\mathrm{LB}$ broth with $0.5 \mathrm{mg} . \mathrm{C} / \mathrm{l}\left(1.64 \times 10^{7} \pm 6.04 \times 10^{6} \mathrm{cfu} / \mathrm{ml}\right)$. The said concentration was used as benchmark to clarify the pathogenic resistance. The comparison between monoculture of probiotic bacteria and co-culture of probiotic bacteria plus pathogenic bacteria indicated that there was non significantly different in growth of the bacterias. Hence extracted polysaccharides from sea graps $(C$. lentilifera) had potential to be utilized not only as a growth enrichment of probiotic bacteria but also inhibiting pathogenic bacteria.
\end{abstract}

Index Terms -Sea grape, seaweed, polysaccharide, prebiotic, probiotic bacteria.

\section{INTRODUCTION}

One of the important sources of polysaccharides is seaweed due to the high content aside from being a source of protein increased food nutrition for animals. Polysaccharides are polymeric carbohydrate molecules composed of long chains of monosaccharide units bound together by glycosidic linkages, and on hydrolysis give the constituent monosaccharides or oligosaccharides.

Manuscript received July 12, 2020; revised October 23, 2020. This work was part of the project the study on efficiency of polysaccharide from Seaweed for applied to prebiotic was supported by National Research Council of Thailand (NRCT).

Anek Sopon is with Marine Ecology and Utilization of Marine Resources Research Unit and Aquatic Resources Research Institute, Chulalongkorn University, Bangkok, Thailand (e-mail: anek.s@chula.ac.th).

Ekthida Thongdet is with Faculty of Veterinary Medicine, Mahanakorn University of Technology, Bangkok, Thailand (e-mail: ekthida.p@hotmail.com).

Porntep Punnarak is with Aquatic Resources Research Institute Chulalongkorn University, Bangkok, Thailand (e-mail: porntep.pu@chula.ac.th).

Sucharat Suksai is with Department of Marine Science, Faculty of Science, Chulalongkorn University, Bangkok, Thailand (e-mail: sucharatsuksai@gmail.com).
Both types of polysaccharide through fermentation processes can be a source of carbon for growth of all types of bacteria.

Polysaccharides are therefore considered as prebiotics and valuable in inhibiting pathogens. As prebiotic, polysaccharide provides carbon source for probiotic which is a group of useful bacteria. In aquaculture Bacillus sp., Lactobacillus sp. and Bifidobacterium are interested and commonly applied bacterial group.

The polysaccharides extracted from red seaweed Grateloupia filicina and Eucheuma spinosum can be counted as growth promoter of the best probiotic bacteria Bifidobacterium. [1], green seaweed Cladomorpha linum nourished growth of bacteria up to 70 percent. [2], brown seaweed Padina australis, P. minor, Sargassum polycystum raised bacterial growth. [3]

Pathogenic bacteria commonly produce a thick, mucous-like, layer of polysaccharide [4] and produce signal communication process between bacterial populations called quorum sensing mechanism. The role of polysaccharide, bioactive and antimicrobial compound extracted from seaweed in interruption of this communication process can be defined as pathogenic bacterial inhibitor. The mechanism is interaction in pathogenic bacterial cell and cell membrane and interrupt intracellular substance uptake and their transportation [5] such as the antimicrobial activity of water extracted compound of red seaweed Polysiphonia lanosa on pathogenic bacteria Salmonella aureus, Escherichia cloacea and Clostridium perfringens. Due to this interested function, seaweed extracts have used as alternative effective and disease controlling methods. [5] [6]

Pathogenic bacteria Vibrio parahaemolyticus is usually found in a free-swimming state; with its motility conferred by a single polar flagellum affixed to inert and animate surfaces including zooplankton, fish, shellfish or any suspended matter underwater [2] and cause of the mass mortality of aquaculture production.

Sea grapes or green cavier (Caulerpa lentilifera) is a green seaweed found commonly both in the Gulf of Thailand and Andaman sea. It contains 33.8 percent carbohydrate. [5] The extraction of polysaccharides from 2 percent weight sea grapes per volume has ability to supplement the growth of bacteria Lactobacillus and Escherichia coli. [6] The utilization of polysaccharides extracted from sea grapes as prebiotics and pathogenic resistant are not well recognized in Thailand. Therefore, it is interesting to clarify how to extract polysaccharide from sea grapes at optimal condition suited for growth of prebiotic bacteria and pathogenic resistance. 


\section{MATERIALS AND METHOD}

\section{A. Preparation of Polysaccharide Extracted from Sea Grapes}

Fresh sea grapes were cleaned by flow through tap water and dried at $60^{\circ} \mathrm{C}$ in hot air oven until had a constant weight. Dried seaweeds were calculated for percentage dried weight, then stored in a hygroscopic container.

Dried sea grapes were extracted using hot water extraction modified method. [7] The ratio of sea grape content to water was 1: $125 \mathrm{~g} / \mathrm{ml}$. The extracted condition was controlled at 80 ${ }^{\circ} \mathrm{C}$ throughout the extraction process for 45 minutes.

\section{B. Preparation Bacillus subtilis and Vibrio parahaemolyticus and Culture Media}

Bacillus subtilis was transferred [8] from the stocked in the LB agar (Luria-Bertani) plate into the LB broth tube, incubated at $30{ }^{\circ} \mathrm{C}$ for 24 hours and used for the further experiments.

Vibrio parahaemolyticus was transferred from the stocked in the TCBS and TSA Agar plate into TSA broth, incubated at $30{ }^{\circ} \mathrm{C}$ for 24 hours and used for the further experiments.

\section{Study on the Growth of B. subtilis Cultured in Polysaccharide Extracted from Sea Grape}

This experiment, 3 treatments of LB broth mixed with polysaccharide extraction from sea grape at $0.5,1.0$, and 2.7 mg.C/l were prepared as treatment group and LB broth without polysaccharide extraction was used as control.

B. subtilis was inoculated into 3 treatments of LB broth mixed with polysaccharide extraction and 1 treatment of control. Each treatment was conducted in triplication. The initial inoculation of $B$. subtilis was $10^{5} \mathrm{cfu} / \mathrm{ml}$. The inoculated tubes were incubated at $30^{\circ} \mathrm{C}$ for 48 hours. Then growth of $B$. subtilis in each treatment were investigated by total plate count technique and compared at 0 (initial), 24, and 48 hours of incubation. The treatment which provided the highest B. Subtilis growth were further study on the potential of probiotic $B$. subtilis on inhibiting pathogenic bacteria $V$. parahaemolyticus.

\section{Study on the Potential of Probiotic B. subtilis on}

\section{Inhibiting Pathogenic Bacteria V. parahaemolyticus}

This experiment, growth of bacteria in co-culture of $B$. subtilis and $V$. parahaemolyticus in LB broth mixed with $0.5 \mathrm{mg} . \mathrm{C} / \mathrm{l}$ of polysaccharide extraction from sea grape (treatment) and LB broth without mixing of polysaccharide extraction (control) were investigated for clarifying the ability of probiotic bacterial B. subtilis on inhibition of pathogen bacteria V. parahaemolyticus. Each treatment was done in triplication.

Both bacteria were inoculated with initial amount of $10^{4}$ $\mathrm{cfu} / \mathrm{ml}$, incubated at $30^{\circ} \mathrm{C}$ and then compared growth by total plate count technique at 0 (initial), 24, and 48 hours after incubation with LB Agar for B. Subtilis and TCBS Agar and TSA Agar for V. parahaemolyticus.

\section{E. Statistical Data Analysis}

Growth of $B$. subtilis cultured in the different concentration of polysaccharide extraction was compared to investigate the potential of adding polysaccharide extraction as prebiotic in culture media.

Growth of B. Subtilis co-cultured with $V$. parahaemolyticus in LB broth mixed with polysaccharide extraction treatment was compared with control to investigate the potential of probiotic $B$. subtilis on inhibiting pathogenic bacteria $V$. parahaemolyticus.

Comparison of growth between treatment were done using One-way ANOVA of SPSS program and represent by mean $\pm \mathrm{SD}$.

\section{RESULTS}

\section{A. The Growth of B. subtilis Cultured in Polysaccharide Extracted from Sea Grape}

Growth of B. subtilis cultured in LB broth media with 3 concentrations of polysaccharide of extracted from sea grape $(0.5, \quad 1.0,2.7 \mathrm{mg} . \mathrm{C} / \mathrm{l})$ and $0 \mathrm{mg} . \mathrm{C} / \mathrm{l}$ of extracted polysaccharide as control were compared at 0,24 , and 48 hours after incubation using total plate count technique, initial inoculation varied between $2.50 \times 10^{4} \pm 3.79 \times 10^{4}$ to $1.55 \times 10^{5} \pm 1.06 \times 10^{5} \mathrm{cfu} / \mathrm{ml}$ (Table I). The results showed that after 24 hours of incubation, the amount of B. subtilis cultured in LB broth with $0.5 \mathrm{mg} . \mathrm{C} / \mathrm{l}$ extracted polysaccharide was $1.64 \times 10^{7} \pm 6.04 \times 10^{6} \mathrm{cfu} / \mathrm{ml}$, significantly $(p<0.05)$ higher than amount of B. subtilis cultured in LB broth with 1.0 and $2.7 \mathrm{mg} . \mathrm{C} / \mathrm{l}\left(3.40 \times 10^{5} \pm 4.98 \times 10^{5} \mathrm{cfu} / \mathrm{ml}\right.$ and non-detected, respectively) and tent to higher than control $\left(4.57 \times 10^{6} \pm 3.38 \times 10^{6} \mathrm{cfu} / \mathrm{ml}\right)$ as showed in Table I and Fig. 1.

After 48 hours of incubation (Table I and Fig. 1), amount of $B$. subtilis cultured in LB broth with $0.5 \mathrm{mg}$. C/l extracted polysaccharide was $5.44 \times 10^{6} \pm 3.45 \times 10^{6} \mathrm{cfu} / \mathrm{ml}$. This amount still higher than that of treatments with $0,1.0$ and 2.7 mg.C/l extracted polysaccharide $\left(1.57 \times 10^{6} \pm 6.07 \times 10^{5}\right.$, $1.42 \times 10^{6} \pm 1.64 \times 10^{6} \mathrm{cfu} / \mathrm{ml}$, and non-detected, respectively).

Due to the highest growth of $B$. subtilis was found in treatment of LB broth with concentration of extracted polysaccharide at $0.5 \mathrm{mg} . \mathrm{C} / \mathrm{l}$. So, this concentration of polysaccharide was used for the study of potential of probiotic $B$. subtilis on inhibiting pathogenic bacteria V. parahaemolyticus.

\section{B. Potential of Probiotic B. subtilis on Inhibiting Pathogenic Bacteria V. parahaemolyticus}

This experiment, growth of $B$. subtilis and $V$. parahaemolyticus which had co-cultured in LB broth mixed with $0.5 \mathrm{mg} . \mathrm{C} / \mathrm{l}$ of polysaccharide extraction from sea grape (treatment) and LB broth without mixing of polysaccharide extraction (control) were compared at 0,24 , and 48 hours after incubation using total plate count technique, initial inoculation of $B$. subtilis and $V$. parahaemolyticus varied between $1.00 \times 10^{5} \pm 1.00 \times 10^{5}$ to $6.00 \times 10^{5} \pm 2.00 \times 10^{5}$ and $8.33 \times 10^{4} \pm 7.64 \times 10^{4}$ to $1.50 \times 10^{5} \pm 1.32 \times 10^{5} \mathrm{cfu} / \mathrm{ml}$, respectively. (Table II). The results showed that there were no different of growth of B. subtilis and $V$. parahaemolyticus in control $\left(6.43 \times 10^{6} \pm 1.49 \times 10^{6}\right.$ and $5.33 \times 10^{6} \pm 1.67 \times 10^{6}$ $\mathrm{cfu} / \mathrm{ml}$, respectively) after 24 hours of incubation. While, the amount of $B$. subtilis in LB broth mixed with $0.5 \mathrm{mg} . \mathrm{C} / \mathrm{l}$ of polysaccharide extraction was $5.33 \times 10^{6} \pm 1.67 \times 10^{6} \mathrm{cfu} / \mathrm{ml}$ 
and V. parahaemolyticus was not founded as showed in Fig. 2 .

After 48 hours of incubation, the amount of B. subtilis and $V$. parahaemolyticus in control were $2.15 \times 10^{6} \pm 1.44 \times 10^{6}$ and $1.38 \times 10^{6} \pm 8.96 \times 10^{5} \mathrm{cfu} / \mathrm{ml}$, respectively. While, amount of $B$. subtilis and $V$. parahaemolyticus in LB broth mixed with $0.5 \mathrm{mg} . \mathrm{C} / \mathrm{l}$ of polysaccharide extraction were
$7.03 \times 10^{6} \pm 2.92 \times 10^{6}$ and $8.12 \times 10^{6} \pm 1.32 \times 10^{5} \quad \mathrm{cfu} / \mathrm{ml}$, respectively. There were no significantly different between amounts of both bacteria after 48 hours of incubation. But amount of B. subtilis cultured in $0.5 \mathrm{mg}$. C/l of polysaccharide extraction seeming higher compared to control and increasing of $V$. parahaemolyticus had investigated (Table II).

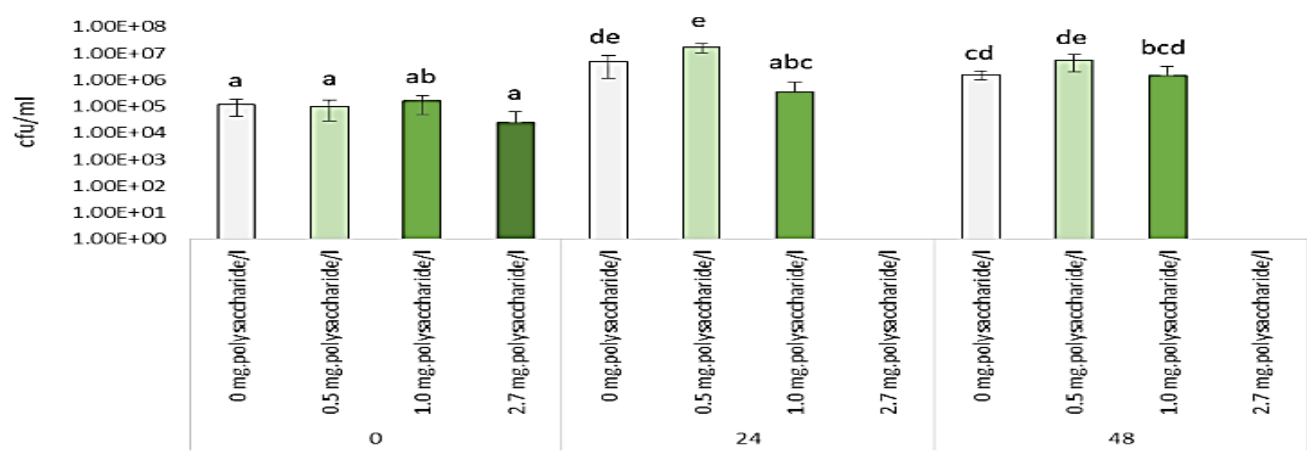

Culture time $(\mathrm{Hr})$

Different letters indicate significant different at $p<0.05$

Fig. 1. The amount of B. subtilis (cfu/ml) cultured in LB broth containing polysaccharide extract from sea grape at various concentrations.

TABLE I: THE AMOUNT OF B. SUBTILIS (CFU/ML) CULTURED IN LB BROTH CONTAINING POLYSACCHARIDE EXTRACT FROM SEA GRAPE AT VARIOUS CONCENTRATIONS

\begin{tabular}{cccc}
\hline $\begin{array}{c}\text { Incubation time } \\
(\mathbf{h})\end{array}$ & $\mathbf{0}$ & Concentration of polysaccharide extracted from sea grape (mg.C/l) & $\mathbf{1}$ \\
\cline { 2 - 4 } & $1.15 \times 10^{5} \pm 7.37 \times 10^{4 \mathrm{a}}$ & $1.00 \times 10^{5} \pm 7.12 \times 10^{4 \mathrm{a}}$ & $1.55 \times 10^{5} \pm 1.06 \times 10^{5 \mathrm{ab}}$ \\
\hline 0 & $4.57 \times 10^{6} \pm 3.38 \times 10^{6 \mathrm{de}}$ & $1.64 \times 10^{7} \pm 6.04 \times 10^{6 \mathrm{e}}$ & $3.40 \times 10^{5} \pm 4.98 \times 10^{5 \mathrm{abc}}$ \\
\hline 24 & $1.57 \times 10^{6} \pm 6.07 \times 10^{5 \mathrm{~cd}}$ & $5.44 \times 10^{6} \pm 3.45 \times 10^{6 \mathrm{de}}$ & $1.42 \times 10^{6} \pm 1.64 \times 10^{6 \mathrm{bcd}}$ \\
\hline 48 & $\mathrm{nd}$ & $\mathrm{nd}$
\end{tabular}

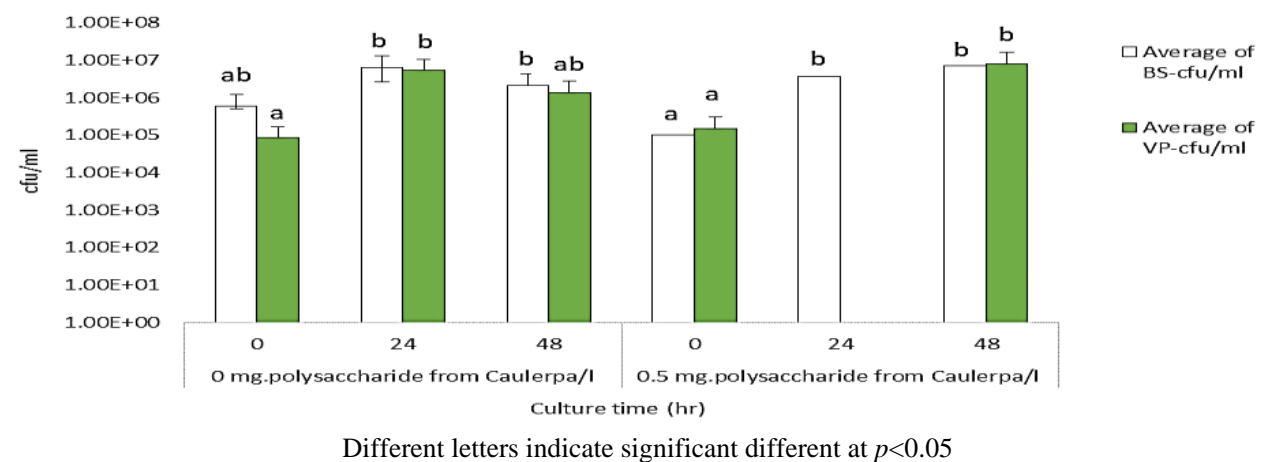

Fig. 2. The amount of B. subtilis and V. parahaemolyticus (cfu/ml) cultured in LB broth containing polysaccharide extracts and control

TABLE II: The AMOUNT OF B. SUBtILIS AND V. PARAHAEMOLYTICUS (CFU/ML) CULTURED IN LB BROTH CONTAINING POLYSACCHARIDE EXTRACTS AND CONTROL

\begin{tabular}{|c|c|c|c|c|}
\hline \multirow{2}{*}{$\begin{array}{c}\text { Incubation } \\
\text { time (h) }\end{array}$} & \multicolumn{2}{|c|}{ B. subtilis } & \multicolumn{2}{|c|}{ V.parahaemolyticus } \\
\hline & 0.0 mg.C of polysaccharide/l & $0.5 \mathrm{mg} . \mathrm{C}$ of polysaccharide/l & 0.0 mg.C of polysaccharide/l & $0.5 \mathrm{mg} . \mathrm{C}$ of polysaccharide/l \\
\hline 0 & $6.00 \times 10^{5} \pm 2.00 \times 10^{5 \mathrm{ab}}$ & $1.00 \times 10^{5} \pm 1.00 \times 10^{5 \mathrm{a}}$ & $8.33 \times 10^{4} \pm 7.64 \times 10^{4 a}$ & $1.50 \times 10^{5} \pm 1.32 \times 10^{5 \mathrm{a}}$ \\
\hline 24 & $6.43 \times 10^{6} \pm 1.49 \times 10^{6 \mathrm{~b}}$ & $3.75 \times 10^{6} \pm 2.03 \times 10^{6 \mathrm{~b}}$ & $5.33 \times 10^{6} \pm 1.67 \times 10^{6 \mathrm{~b}}$ & nd \\
\hline 48 & $2.15 \times 10^{6} \pm 1.44 \times 10^{6 \mathrm{~b}}$ & $7.03 \times 10^{6} \pm 2.92 \times 10^{6 \mathrm{~b}}$ & $1.38 \times 10^{6} \pm 8.96 \times 10^{5 \mathrm{ab}}$ & $8.12 \times 10^{6} \pm 1.32 \times 10^{5 b}$ \\
\hline
\end{tabular}

\section{DISCUSSION}

The properties of extracted polysaccharides as carbon source for probiotic bacteria is interested. The composition of polysaccharides derived from seaweed considered as a sulfated polysaccharides, which is a type of polysaccharides that are different from terrestrial plants and also provide biological properties whether it is an antioxidants including immunological and inhibition effects on infections and tumours as well. [9] The composition of polysaccharides in Caulerpa racemose consisted of glucose, arabinose, galactose, mannose xylose and ramnose which correspond to 
the composition of the polysaccharides in C. lentillifera and C. sertulariodes. [10]-[12]

It had been reported that $C$. prolifera had a high ratio of sugar to sulfate and had more than 50 percent resistance to viral infections. While $C$. sertularioides shown the ability to inhibit free radicals more than 10 percent compared to red algae and brown algae. [13] In addition, the oligosaccharide extracted from $C$. racemose, was also found in the form of $\alpha-(1 \rightarrow 4)$ glucose after being hydrolyzed, and have been classified as gluco-oligosaccharides which can be a good source of carbohydrates for bacteria to grow. [10], [14] Furthermore, it had been reported that Bacillus spp. isolated from digestive tract of turbot at the weaning stage had higher growth when used Raftilose P5 which is the oligofructose as carbon source compared with glucose [15]. This result revealed the importance of oligosaccharide on growth of probiotic such as $B$. subtilis in aquaculture.

Comparing the growth of $B$. subtilis cultured in LB broth (control) and LB broth mixed with polysaccharide extract from sea grape revealed that the medium mixed with polysaccharide extracted from sea grape $0.5 \mathrm{mg}$.C/l promoted significantly highest amount of bacteria $B$. subtilis $\left(1.64 \times 10^{7}\right.$ $\left.\pm 6.04 \times 10^{6} \mathrm{cfu} / \mathrm{ml}\right)$ compared to control an another concentration of extracted polysaccharide after 24 hours of incubation. This may be due to obtaining oligosaccharide as additional carbon sources for bacterial growth. Oligosaccharide probably was hydrolysed from polysaccharide during sea grape extraction process according to the study of $C$. racemose polysaccharide extraction, oligosaccharide in $\alpha-(1 \rightarrow 4)$ glucose form was found after hydrolyzation of polysaccharide [11], [14].

In contrast, B. subtilis cultured in only polysaccharide extraction which is contained $2.7 \mathrm{mg}$. $\mathrm{C} / \mathrm{l}$ did not promote the growth of bacteria. Therefore, there was a possibility that, the polysaccharide extracted from sea grape may inhibit the growth of $B$. subtilis or insufficient carbon sources for bacterial growth.

A possibility in inhibition on growth of B. subtilis by seaweed extraction have been reported in the study between green seaweed $C$. prolifera, $C$. racemosa and $C$. webbiana and growth of $B$. subtilis MB964. But seaweeds were extracted by methanol and growth of bacteria was investigated using the inhibition zone. However, there was the interesting explanation about the inhibition process of seaweed extract on growth of bacteria which the anticoagulant and antioxidant activities. The $0.01-2.00$ $\mathrm{mg} / \mathrm{ml}$ polysaccharide from $C$. prolifera had antiproliferative efficacy on HeLa cell proliferation $(36.3-58.4 \%)$ and the result showed the positive correlation between sulfate content and antiproliferative efficacy. The sulfated polysaccharides extracted from $C$. lentilifera at concentration $2.7 \mathrm{mg} . \mathrm{C} / \mathrm{l}$ in this study may had ability of antioxidant and antiproliferation against the growth of B. subtilis. [16], [17]

In addition, those two possibilities may showed in the result of lesser growth of $B$. subtilis cultured in control and LB broth mixed with $1 \mathrm{mg}$. C/l of polysaccharide extraction compared with significantly higher growth of $B$. subtilis cultured in LB broth mixed with $0.5 \mathrm{mg} . \mathrm{C} / \mathrm{l}$ of polysaccharide extraction. Higher concentration of $1 \mathrm{mg} . \mathrm{C} / \mathrm{l}$ of polysaccharide extraction in LB broth may slightly inhibit the growth of bacteria. While, lower carbon source in control compared to treatment with $0.5 \mathrm{mg} . \mathrm{C} / 1$ of polysaccharide result in lower growth of $B$. subtilis as well. However, the inhibition of this seaweed extract on growth of bacteria still need the further study.

The results of the studying on the potential of probiotic $B$. subtilis on inhibiting pathogenic bacteria $V$. parahaemolyticus showed that growth of B. subtilis and $V$. parahaemolyticus when cultured together in LB broth containing with polysaccharide $0.5 \mathrm{mg} . \mathrm{C} / \mathrm{l}$ at $24 \mathrm{hr}$ of the cultivation were significantly difference due to growth of $V$. parahaemolyticus were low and could not be detected. This result was similar with variation of Vibrio sp. and Bacillus sp. in intestinal tract of weaning turbot. Before feeding with oligofructose Vibrio spp. represented $96 \%$ of the isolation. But the proportion of Vibrio sp. was reduced, and Bacillus sp. was increased after fed with oligosucrose. In addition, Bacillus spp. have been reported and evaluated as probiotic and biocontrol due to their abilities of water quality improvement, reducing the incidence of pathogen especially Vibrio sp. [18].

However, the growth of both $B$. subtilis and $V$. parahaemolyticus were not showed the significantly difference after the $48 \mathrm{hr}$ of cultivation in LB broth containing with polysaccharide $0.5 \mathrm{mg}$. C/l. This result may due to the co-utilization of two bacteria.

\section{CONCLUSION}

The supplementation of polysaccharides from sea promoted the best $B$. subtilis growth at the concentration of $0.5 \mathrm{mg} . \mathrm{C} / \mathrm{l}$ when compared to the control and the other concentration treatment of supplemented polysaccharides. When culture B. subtilis together with $V$. parahaemolyticus in culture media containing polysaccharide supplemented for $0.5 \mathrm{mg} . \mathrm{C} / \mathrm{l}$ of seaweed in both varieties, the growth of $B$. subtilis was significantly higher than growth of $V$. parahaemolyticus after 24 hours of cultivation, but there was not significantly different after 48 hours of cultivation. In consequence extracted polysaccharides from sea graps (C. lentilifera) had potential to be utilized not only as a growth enrichment of probiotic bacteria but also inhibiting pathogenic bacteria.

\section{CONFLICT OF INTEREST}

The authors declare no conflict of interest.

\section{AUTHOR CONTRIBUTIONS}

Anek Sopon, Ekthida Thongdet and Sucharat Suksai work in the laboratories; Porntep Punnarak analyzed data statistic; Anek Sopon wrote the paper; all authors had approved the final version.

\section{ACKNOWLEDGEMENT}

This article is a part of the project of the study on efficiency of polysaccharide from Seaweed for applied to prebiotic and was supported by National Research Council of Thailand (NRCT).

This study was courtesy of sea grape Caulerpa lentillifera 
from the Phetchaburi Coastal Fisheries Development Center and Family farm, the commercial sea grape farm, in Phetchaburi Province.

\section{REFERENCES}

[1] X. Chen, Y. Sun, L. Hu, S. Liu, H. Yu, R. Li, X. Wang, and P. Li, "In vitro prebiotic effects of seaweed polysaccharides", Journal of Oceanology and Limnology, vol. 36, no. 3, pp. 926-932, 2018.

[2] F. Goecke, A. Labes, J. Wiese, and J. F. Imhoff, "Dual effect of macroalgal extracts on growth of bacteria in Western Baltic Sea," Revista de biología marina y oceanografía, vol. 47, no. 1, pp. 75-86, 2012.

[3] A. Kantachumpoo and A. Chirapart, "Components and antimicrobial activity of polysaccharides extracted from Thai brown seaweeds," Kasetsart Journal (Natural Science), vol. 44, no. 2, pp. 220-233, 2010

[4] C. J. Gode-Potratz, R. J. Kustusch, P. J. Breheny, D. S. Weiss, and L. L. McCarter, "Surface sensing in Vibrio parahaemolyticus triggers a programme of gene expression that promotes colonization and virulence," Mol.Microbiol., vol. 79, pp. 240-263, 2011.

[5] S. Thanigaivel, J. Thomas, A. Mukherjee, and N. Chandrasekaran, "Seaweed as an alternative therapeutic source for aquatic disease management," Aquaculture, vol. 464, pp. 529-536, 2016.

[6] M. J. Pérez, E. Falqué, and H. Domínguez, "Antimicrobial action of compounds from marine seaweed," Mar Drugs, vol. 9, no. 14, pp. 1-38, 2016.

[7] N. Kaliaperumal, S. Kalimuthu, and J. Ramalingam, "Economically important seaweeds," CMFRI Special Publication, vol. 62, pp. 1-35, 1995.

[8] M. Kho, R. Hernandez, J. Ladera, D. Khow, V. Lagura, J. Jacinto, and P. Medina, "In vitro assessment of the prebiotic potential of Caulerpa lentillifera, Gracilaria arcuata, and Sargassum polycystum on probiotic Lactobacillus species," International Journal of Bioscience, pp. 382-388, 2017.

[9] K. Chattopadhyay, U. Adhikari, P. Lerouge, and B. Ray, "Polysaccharides from Caulerpa racemosa: Purification and structural features," Carbohydrate Polymers, vol. 68, no. 3, pp. 407-415, 2007.

[10] G. Paradossi, F. Cavalieri, L. Pizzoferrato, and A. M. Liquori, "A physico-chemical study on the polysaccharide ulvan from hot water extraction of the macroalga Ulva," International Journal of Biological Macromolecules, vol. 25, no. 4, pp. 309-315, 1999.

[11] G. S. Ferreira, N. C. Bolívar et al., "Microbial biofloc as source of probiotic bacteria for the culture of Litopenaeus vannamei," Aquaculture, vol. 448, pp. 273-279, 2015.

[12] P. Ghosh, U. Adhikari, P. K. Ghosal, C. A. Pujol, M. A. J. Carlucci, E. B. Damonte, and B. Ray, "In vitro anti-herpetic activity of sulfated polysaccharide fractions from Caulerpa racemosa," Phytochemistry, vol. 65, no. 23, pp. 3151-3157, 2004.

[13] N. Shevchenko, Y. V. Burtseva, T. Zvyagintseva, T. Makar, O. Sergeeva, A. Zakharenko, V. Isakov, N. T. Linh, N. X. Hoa, and B. M. Ly, "Polysaccharides and sterols from green algae Caulerpa lentillifera and C. sertularioides," Chemistry of Natural Compounds, vol. 45, no. 1, pp. 1-5, 2009.

[14] L. Wang, X. Wang, H. Wu, and R. Liu, "Overview on biological activities and molecular characteristics of sulfated polysaccharides from marine green algae in recent years," Marine Drugs, vol. 12, no. 9 , pp. 4984-5020, 2014

[15] A. Mahious, F. Gatesoupe, M. Hervi, R. Metailler, and F. Ollevier, "Effect of dietary inulin and oligosaccharides as prebiotics for weaning turbot, Psetta maxima (Linnaeus, C. 1758)," Aquaculture International, vol. 14, no. 3, p. 219, 2006.

[16] L. Costa et al., "Biological activities of sulfated polysaccharides from tropical seaweeds," Biomedicine \& Pharmacotherapy, vol. 64, no. 1, pp. $21-28,2010$.

[17] J. Grimoud, H. Durand, C. Courtin, P. Monsan, F. Ouarné, V. Theodorou, and C. Roques, "In vitro screening of probiotic lactic acid bacteria and prebiotic gluco-oligosaccharides to select effective synbiotics," Anaerobe, vol. 16, no. 5, pp. 493-500, 2010.

[18] A. Val et al., "Screening of antimicrobial activities in red, green and brown macroalgae from Gran Canaria (Canary Islands, Spain)," International Microbiology, vol. 4, no. 1, pp. 35-40, 2001.

Copyright $\odot 2020$ by the authors. This is an open access article distributed under the Creative Commons Attribution License which permits unrestricted use, distribution, and reproduction in any medium, provided the original work is properly cited (CC BY 4.0).

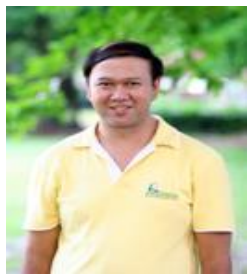

Anek Sopon was born in Phatthalung province, Thailand in March 1967. He got his bachelor degree in the Department of Aquaculture and master degree in Fisheries Science from Faculty of Fisheries, Kasetsart University, Thailand in April 1989 and April 1992, respectively. $\mathrm{He}$ is a researcher at Aquatic Resources Research Institute, Chulalongkorn University, Thailand, since 1995. His current research interests are in field of coastal aquaculture and utilisation of seaweed.

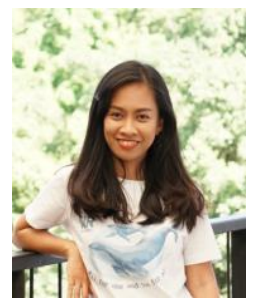

Ekthida Thongdet was born in Ranong province, Thailand in August 1983. She got her bachelor degree in aquatic science from Prince of Songkla University, Thailand in May 2006 and got her master degree in marine science from Chulalongkorn University, Thailand in may 2011. After graduation in master degree, she was researcher in research and development section for private aquaculture company during 2011-2014. Currently, she is Ph.D. candidate in marine science at Chulalongkorn University and lecturer at aquatic animal clinic, faculty of veterinary medicine, Mahanakorn University, Thailand. Her current research interests are aquatic animal health, especially in nutrition, disease and prevention.

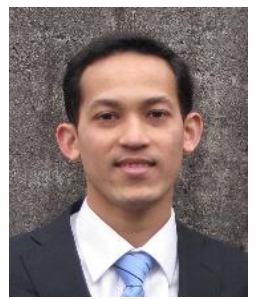

Porntep Punnarak was born in Ratchaburi province, Thailand in September 1979. He got his bachelor and master degree in marine science from Chulalongkorn University, Thailand in April 2002 and April 2005, respectively. He got his Ph.D. in applied marine bioscience from Tokyo University of Marine Science and Technology, Tokyo, Japan in March 2012.

$\mathrm{He}$ is a researcher at the Aquatic Resources Research Institute, Chulalongkorn University, Thailand, since 2013. His current research interests are in the fields of biology, taxonomy and ecology of plankton in coastal and marine environments, aquaculture of microalgae and zooplankton, and the application of molecular techniques in marine biology and ecology. 